Article

\title{
Assessment of the Degree of Factors Impact on Employment in Ukraine's Agriculture
}

\author{
Nataliia Patyka ${ }^{1}\left(\mathbb{D}\right.$, Olena Gryschenko $^{1}\left(\mathbb{D}\right.$, Anatolii Kucher ${ }^{2}\left(\mathbb{D}\right.$, Maria Hełdak $^{3, *(\mathbb{D}}$ and Beata Raszka ${ }^{3}(\mathbb{D})$ \\ 1 National Scientific Centre "Institute of Agrarian Economics", 10, Heroiv Oborony st., 03127 Kyiv, Ukraine; \\ n_patyka@ukr.net (N.P.); lena@iae.kiev.ua (O.G.) \\ 2 Department of Ecology and Neoecology, V. N. Karazin Kharkiv National University, Svobody 6, \\ 61022 Kharkiv, Ukraine; kucher@karazin.ua \\ 3 Institute of Spatial Economy, Wroclaw University of Environmental and Life Sciences, ul. Grunwaldzka 55, \\ 50-357 Wrocław, Poland; beata.raszka@upwr.edu.pl \\ * Correspondence: maria.heldak@upwr.edu.pl
}

Citation: Patyka, N.; Gryschenko, O.; Kucher, A.; Hełdak, M.; Raszka, B. Assessment of the Degree of Factors Impact on Employment in Ukraine's Agriculture. Sustainability 2021, 13,

564. https://doi.org/10.3390/ su13020564

Received: 23 October 2020 Accepted: 29 December 2020 Published: 8 January 2021

Publisher's Note: MDPI stays neutral with regard to jurisdictional clai$\mathrm{ms}$ in published maps and institutional affiliations.

Copyright: (C) 2021 by the authors. Licensee MDPI, Basel, Switzerland. This article is an open access article distributed under the terms and conditions of the Creative Commons Attribution (CC BY) license (https:// creativecommons.org/licenses/by/ $4.0 /)$.

\begin{abstract}
Agriculture is an important branch in Ukraine's economy. The share of agriculture's GDP in the national economy is more than $10 \%$. The development of agriculture stimulates the development of other sectors in national economy. According to the results of the analysis of the employment dynamics in Ukraine's agriculture, it was concluded that there was a negative tendency. That is why the aim of the article is to specify the factors of impact on employment in Ukraine's agriculture and to assess the degree of their influence. To achieve this goal, the different methods were used: system analysis-for determination the factors influencing employment in agriculture; factor analysis, multiple regression analysis, principal components method-for evaluating the impact of various factors on the employment in agriculture of Ukraine. It was found that the most significant social-demographic factors of impact on employment in Ukraine's agriculture include the total rural population at the age 16-64 and the demand for labor force in agriculture, and the most important economic factor is labor productivity. Determining the factors and measures of their impact on employment will substantiate public policy measures, methods and mechanisms for their implementation to solve employment problems in Ukraine's agriculture.
\end{abstract}

Keywords: employment; factors; economic and mathematical modelling; principal components method; agriculture; Ukraine

\section{Introduction}

Agriculture has historically played an important role in the development of Ukraine's economy. That branch supplies the population with food, and provides the food security and food independence of the country. Due to the great economic and natural resource potential (41.5 million ha of agricultural lands, reaching $68.7 \%$ of the total land fund, one third of Ukraine's population lives on rural territory, favorable natural and climatic conditions), our country is deeply integrated into the global agro-food markets and increases its competitive capacity. Recently, the importance of agriculture at the international commodities markets has increased, supplying inflow of foreign currency into our country, strengthening its political-economic positions in the globalized world space, and contributing to the general economic growth.

However, along with the above-mentioned positive aspects, the social-economic development of the branch is also characterized by negative tendencies. In particular, they are revealed in the insufficient level of state support for agriculture, depression of the social infrastructure in villages, reduction in the rural population, low level of income, growth of the intensity of labor migration, etc. The identified negative phenomena prevent revealing the potential of the agrarian sphere in Ukraine to the full. 
The issues of rural population employment are of great interest for many scientists. A significant contribution to the problems studying, particularly determination of tendencies, directions to increase the level of population employment, introduction of organizational, legal, social, economic and other mechanisms of its support has been made by such domestic scientists as Bandur, S. [1], Bulavka, O. et al. [2], Gnybidenko, I. [3], Nartiuk, O. [3,4], Hrishnova, O. [5], Kurylo, I. [6], Cheren'ko, L., Libanova, E., Makarova, O. [7], Malik, M., Mamchur, V. [8], Gadzalo, J. et al. [9], Petrova, L. [10] and others [11]. Bulavka, O., Diiesperov, V., Kapinus, M., Samofal, O., Hrabovska, L., focusing attention on the connection between the wage in agriculture and the level of employment in the branch [2], studying the peculiarities of rural population employment and their main tendencies. As an important factor of employment in agriculture Pavliuk, T. determines the seasonality of agricultural production, which is due to natural and climatic conditions and the specifics of social factors of peasants' different lifestyles [12]. In turn, Kukel, G. et al. argued the following main factors influencing the processes taking place in the agricultural labor market: the structural restructuring of Ukraine's economy, in particular the predominant development of the agricultural sector; strengthening the potential of entrepreneurship; scientific and technological progress, informatization of society; state regulation of labor potential, labor market and employment [13]. An important aspect concerning the support of rural employment is elaborated in the works by Malik, M. and Mamchur, V., who pay attention to the fact that while developing practical recommendations concerning the principal directions of rural employment, it is necessary to shape the ways to diversify activities with consideration of the main non-agricultural works [8]. The diversity of social-economic problems of rural population employment and their analysis is elucidated in the research by Riabokon, V. [14]. Based on the study of the dynamics and condition of the rural population employment, many researchers pay attention to the identification of priority areas of rural development in order to preserve labor potential [15].

Along with the domestic scientists, the problems of employment in the agrarian sector are examined by foreign researchers, also under the authority of international organizations. That fact shows the importance of the problem in the world. In particular, they study general aspects of employment in different countries, investigate the impact of different factors, including income, investments, the size of agricultural enterprises, volume of production on the rural labor market and efficiency in agriculture, analyze the issue of non-elastic employment, and consider flexibility concerning the salary size, practice of hiring and firing of employees, effectiveness of public policy measures, including the EU's Common Agricultural Policy, on employment in agriculture, etc. [15-35]. For example, Kerstin, N. and Ostermeier, M. in their research demonstrate the negative impact of investment associated with increasing the size of agricultural enterprises, with increasing production of capital-intensive crops on employment in agriculture [18]. Sumedh, R. shows the link between employment and increasing agricultural production and argues that the relationship varies as a result of the type of produce, the structure of the business (e.g., small landowner versus larger agribusiness) and the wider economy as a whole. Growth of the secondary and tertiary sectors in an economy and non-farm income opportunities can reduce the supply of cheap and available labor. Social factors such as migration, and in particular rural to urban migration, can have a similar effect [24]. Petrick, M. and Zier, $\mathrm{P}$ based on their own research concluded that a rise in the general wage level reduced labor use in agriculture, changes in direct payments had no employment effects [29]. The research results, conducted by Chaplina, $\mathrm{H}$. et al., indicate that the enterprise diversification by farmers is unlikely to generate sufficient new jobs to solve the problem of high rural unemployment etc. [32]. Urquía-Grande, E. and del-Campo, C. in their study presented which socio-demographic and economic variables determine families' different commitments in rural Ethiopia [35].

Numerous scientific publications are also focused on other important aspects of the problem of rural population employment, social and economic transformations in the agrarian sector, identification of the problems and prospects of sustainable development of 
rural territories, particularly in the context of decentralization, European integration and globalization [36-49]. However, in spite of the great scope of scientific research, the issues of determination of the factors influencing employment in the domestic agriculture, need a deeper investigation. A deep analysis of those factors and determination of their impact are relevant topics as they are necessary for the development of the future effective state policy concerning social and economic development of the country, support for the growth of employment in agriculture, and to enhance the branch competitiveness.

In economics, there are numerous theories of employment, which consider the factors influencing employment. In particular, Smith, A. [50] and Say, J.-B. [51] in the classical theory of employment define the market as a self-regulating system that allows full employment of the population under the condition of absolute non-interference of the state in economic processes.

In contrast, Keynesian theory of employment by Keynes, J.M. [52] calls unemployment a natural phenomenon, and employment requires active state intervention in labor market relations. Neoclassical (Marshall, A., etc.) and neoliberal (Hayek, F., Pigou, A., etc.) theories [53], the rational expectations theory (Lucas, R.E. [54], etc.) consider the market (including the labor market) as a self-regulating system with perfect competition. In the context of these theories, state intervention in the process of providing employment through the regulation of prices, credit interest, supply and demand (Marshall, A.), the distribution of national income through the system of taxes and subsidies (Pigou, A.) is either absent or insignificant.

Representatives of Neo-Keynesian theories, such as the theory of the economic cycle (Hansen, A. [55,56]), the theory of economic growth (Harrod, R. [57,58], Domar, E. [55]) studied the problem of choosing between employment and inflation rate. Thus, Harrod, R. [58] studied the dynamics of economic factors such as labor force, available capital and production output or per capita income and identified the continuous growth of income as one of the most important factors in the entire economic system. Hansen, A. [56] and Domar, E. [55] with the help of the ratio of the growth of investment to the relative growth of income that caused these investments, proved the inverse relationship between the growth of national income and employment and the subsequent growth of investment.

One of the main signs of employment, according to representatives of the concept of human development (Sen, A. [59]) is to obtain and increase income. According to the theory of human capital (Schultz, T. [60], Becker, G. [61], etc.), employment is considered as one of the means of obtaining and growing income and its subsequent investment in education, health care, child rearing, etc. Under the absence of decent work conditions, income from employment will not fully meet the basic needs of the population. In addition, productive employment, according to the theory of human capital, is also the goal of socio-economic and political development, a way to achieve them, a tool for socialization, sphere of communication and recognition of the population.

Given the current conditions of the Ukrainian economy, determining and assessing the impact of factors on employment in agriculture to focus on one of the many existing theories of employment is impossible. In our opinion, such analysis and assessment should be based on a symbiosis of various theories, including Keynesian theory, the theory of economic growth and the concept of human development.

The aim of the article is to specify the factors of impact on employment in Ukraine's agriculture and to assess the degree of their influence basing on the economic and mathematic analysis.

\section{Materials and Methods}

In order to achieve the defined aim, the following research tasks were formulated:

- $\quad$ to analyze the current conditions and to identify trends in employment in Ukraine's agriculture,

- $\quad$ to identify and systematize the basic factors influencing employment in agriculture of Ukraine, 
- $\quad$ to assess the degree of the factors' impact on employment in Ukraine's agriculture.

The dialectical method of scientific cognition was used to solve the tasks of research and achieve the set purpose, as well as general scientific and special methods. In analyzing the current condition of employment in Ukraine's agriculture and for assessing the trends of employment, methods of statistical analysis were used: method of averages and relative values, trend analysis, the comparative analysis in order to compare the results obtained in individual years. It was done to establish certain relationships, such as identity, similarity or difference between the characteristics and facts.

The system analysis was used for the determination of the factors influencing the number of people employed in agriculture and their next classification.

Modelling of employment in agriculture as a branch of the national economy and evaluating the impact of various factors are made by applying the method of factor analysis to develop a regression equation on the whole time interval (2000-2019) of collected relevant data. The authors used statistical data, which were the social-demographic and economic factors of impact on the dynamics of the indicator of the number of people employed in agriculture. The principal component method was used for reducing the model size (to reduce the dimensionality of data without losing the information) and presenting it in a more compact and convenient form.

Abstract-logical method was used for generalizing scientific and methodological approaches to the study of the employment in Ukraine's agriculture and formulation of conclusions.

The information base of the research was the data of the State Statistics Service of Ukraine [62].

The methodology used in the study follows the below steps (Figure 1). It should be noted that collecting statistical information and developing the database covering: the number of population, employed in Ukraine's agriculture, the number of registered unemployed people among rural population, labor demand in agriculture, wages in the agrarian sector, the number of those economically active among the rural population, the GDP of agriculture, investments in agriculture, export and import of agricultural products, gross added value in agriculture, agricultural production, labor productivity, share of animal production and crop production in the total outcome, amounts of sold products and other macroeconomic indicators.

-identification of the research subject and selection of the study area

- analysis of the scientific literature

- collecting statistical information and developing the database

- analysis of the conditions of employment in Ukraine's agriculture in the years 1990-2018

-identification and systematization of factors influencing employment in agriculture of Ukraine

- modeling of employment in Ukraine's agriculture and assessment of the degree of main factors impact (the research period covers 1990-2019)

- conclusions

Figure 1. Logical scheme of research methodology. Reference source: composed by the authors. 


\section{Results}

\subsection{The Current Conditions of Employment in Ukraine's Agriculture}

The current conditions of employment in agriculture have experienced great transformations, caused by changes of the role and format of the agrarian sector's impact on the development of Ukraine's national economy in total. Nowadays, employment in domestic agriculture is characterized by the following tendencies:

- changes in the structure of agricultural production. The volume of agricultural production in crop production, being a less labor consuming branch, has recently increased, whereas in animal production the situation is different (Table 1). Thus, the volume of crop products increased by $36.5 \%$ in 1990-2018 and amounted for UAH 198658.1 million in 2018. However, the volume of products of animal production was reduced by $48.4 \%$ and amounted to UAH 70,750.0 million in 2018 .

- $\quad$ reduction in the sphere of agricultural works. In spite of the recent growth of the volume of gross products of agriculture, there is a strong tendency to reduction in the number of people employed in the branch. In 2000-2003, the share of people employed in agricultural production was equal to $21.6-20.4 \%$ of the total number of employed population, whereas in $2007-2010$, it was reduced to $15-16 \%$ and little increased up to $17.5-18.2 \%$ in 2015-2019 [62];

- disproportion of the conjuncture of rural labor markets. In 2005-2015, the number of unemployed per one job vacancy at the enterprises of agriculture, hunting and forestry industry increased four times, i.e., from 44 people in 2005 to 173 people in 2015 (Table 2).

Table 1. Structure of agricultural products (in constant prices of 2010), \%.

\begin{tabular}{ccccccccc}
\hline Indicators & \multicolumn{9}{c}{ Year } & $\begin{array}{c}\text { 2018 as Compared to 1990, } \\
\text { Percentage Points (p.p.) }\end{array}$ \\
\cline { 2 - 9 } & $\mathbf{1 9 9 0}$ & $\mathbf{1 9 9 5}$ & $\mathbf{2 0 0 0}$ & $\mathbf{2 0 0 5}$ & $\mathbf{2 0 1 0}$ & $\mathbf{2 0 1 5}$ & $\mathbf{2 0 1 8}$ & - \\
\hline $\begin{array}{c}\text { Agricultural } \\
\text { products }\end{array}$ & 100 & 100 & 100 & 100 & 100 & 100 & 100 & +22.2 \\
$\begin{array}{c}\text { Crop products } \\
\text { Animal products }\end{array}$ & 51.5 & 57.8 & 61.5 & 63.7 & 63.9 & 70.3 & 73.7 & -22.2 \\
\hline
\end{tabular}

Reference source: calculated by the authors referring to the data of the State Statistics Service of Ukraine [62].

Table 2. Dynamics of unemployment and demand of agricultural enterprises for employees in 2002-2018.

\begin{tabular}{|c|c|c|c|c|c|c|c|c|}
\hline \multirow{2}{*}{ Indicators } & \multicolumn{7}{|c|}{ Year } & \multirow{2}{*}{$\begin{array}{l}2018 \text { as Compared } \\
\text { to } 2002, \%\end{array}$} \\
\hline & 2002 & 2005 & 2010 & 2015 & 2016 & 2017 & 2018 & \\
\hline $\begin{array}{l}\text { Number of registered unemployed people } \\
\text { among rural population, thousands people }\end{array}$ & 423.6 & 452.7 & 236.1 & 207.0 & 180.7 & 165 & 158.5 & 37.4 \\
\hline $\begin{array}{c}\text { Demand of the enterprises of agriculture, } \\
\text { hunting and forestry for employees, } \\
\text { thousand people }\end{array}$ & 7.1 & 10.4 & 2.7 & 1.2 & 1.5 & 2.2 & 2.5 & 35.2 \\
\hline $\begin{array}{l}\text { Number of unemployed per } 1 \text { job vacancy, } \\
\text { people }\end{array}$ & 60 & 44 & 88 & 173 & 120 & 75 & 64 & 106.7 \\
\hline $\begin{array}{c}\text { Total demand of enterprises for employees } \\
\text { (generally in the economy), } \\
\text { thousand people }\end{array}$ & 123.9 & 186.5 & 63.9 & 25.9 & 36.0 & 50.4 & 58.4 & 47.1 \\
\hline $\begin{array}{l}\text { Share of job vacancies in the agrarian } \\
\text { sphere in their total amount } \\
\text { (2nd line } \div 4 \text { th line } \times 100), \%\end{array}$ & 5.73 & 5.58 & 4.23 & 4.63 & 4.2 & 4.37 & 4.28 & -1.45 p.p. \\
\hline
\end{tabular}


This confirms a strong tendency of misbalancing of the conjuncture of the rural labor market in the direction of increase in the labor supply of working-age rural population under a low demand for it. Recently, the situation at the rural labor market has improved, i.e., the number of unemployed per one job vacancy at the enterprises of agriculture, hunting and forestry industries reduced to 64 people in 2016-2018. However, the share of job vacancies in the agrarian sphere in their total amount in Ukraine is still at a low level (4.28\%). Moreover, the indicator reduced by 1.45 p.p. in 2002-2018 (Table 2).

- $\quad$ reduction in the number and sometimes total absence of new job vacancies. According to the statistical data (see Table 2) in 2005-2016, the dynamics of enterprises' demand for employees in agriculture, hunting and forestry industries continuously reduced. At the end of 2016, the demand for employees in agriculture was at the level of 1.5 thousand people. In 2017, the increasing trend of labor demand was initiated and it amounted for 2.5 thousand people in 2018. However, the share of vacancies in the agrarian sphere was generally insignificantly reduced, i.e., by $4.28 \%$;

- low labor productivity. Labor productivity is an important indicator of the economy's competitive capacity, including agriculture. The characteristics of modern agriculture include its low level, whereas the statistical data confirm a recent seven times increase in the labor productivity in agriculture, particularly in crop production-6.21 times, in animal production-almost 9.56 times (Table 3).

Table 3. Labor productivity in Ukraine's agriculture.

\begin{tabular}{|c|c|c|c|c|c|c|}
\hline \multirow{2}{*}{ Year } & \multicolumn{3}{|c|}{$\begin{array}{l}\text { Per } 1 \text { Employed in Agricultural Production, } \\
\text { in Constant Prices of 2010; UAH }\end{array}$} & \multicolumn{3}{|c|}{ In $\%$ as Compared to the Previous Year } \\
\hline & $\begin{array}{l}\text { Agricultural } \\
\text { Production }\end{array}$ & $\begin{array}{l}\text { Crop } \\
\text { Production }\end{array}$ & $\begin{array}{l}\text { Animal } \\
\text { Production }\end{array}$ & $\begin{array}{l}\text { Agricultural } \\
\text { Production }\end{array}$ & $\begin{array}{c}\text { Crop } \\
\text { Production }\end{array}$ & $\begin{array}{l}\text { Animal } \\
\text { Production }\end{array}$ \\
\hline 1991 & 42,827 & 49,188 & 36,507 & 85 & 82.6 & 88.6 \\
\hline 1995 & 30,255 & 45,822 & 17,596 & 97.2 & 97.6 & $\ldots$ \\
\hline 2000 & 27,067 & $\ldots$ & $\ldots$ & 112.3 & $\ldots$ & $\ldots$ \\
\hline 2005 & 72,622 & 86,198 & 47,993 & 114.6 & 110.4 & 133 \\
\hline 2010 & 132,680 & 133,603 & 130,474 & 101 & 96.3 & 114.5 \\
\hline 2014 & 227,753 & 228,885 & 224,105 & 109.1 & 108.2 & 111.6 \\
\hline 2015 & 223,310 & 218,768 & 237,990 & 98 & 95.6 & 106.2 \\
\hline 2018 & 313,627 & 305,315 & 348,901 & 115.5 & 117.1 & 110.6 \\
\hline $\begin{array}{l}2018 \text { as compared } \\
\text { to } 1991\end{array}$ & 7.32 times & 6.21 times & 9.56 times & - & - & - \\
\hline
\end{tabular}

Reference source: calculated by the authors referring to the data of the State Statistics Service of Ukraine [62].

Such a tendency manifests a growth of enterprises' profitability and outcome of products. However, it has a contradictory impact on employment, because labor productivity can be improved due to the automation of actions and processes, and robot automation that results in staff redundancy;

- $\quad$ low wages in the agrarian sector of economy. In spite of the increasing wage of people employed in agriculture, its size is still lower than the wage of people engaged in industry and amounts for $74.1 \%$ of the wage of the last (Figure 2).

Considering the above-mentioned, one can conclude about a significant differentiation of the income of working-age rural population, loss of the value of rural work, growth of poverty and intensification of social and property differentiation and consequently, outflow of the economically active population from the rural territory;

- reduction in economically active rural population and deformation of its age structure, i.e., according to the statistical data, $41 \%$ of the rural residents are retired people, and almost $18 \%$ of rural residents have reached the age of 65 years [62]. Therefore, the share of population of the older working age increases at the rural labor market. 


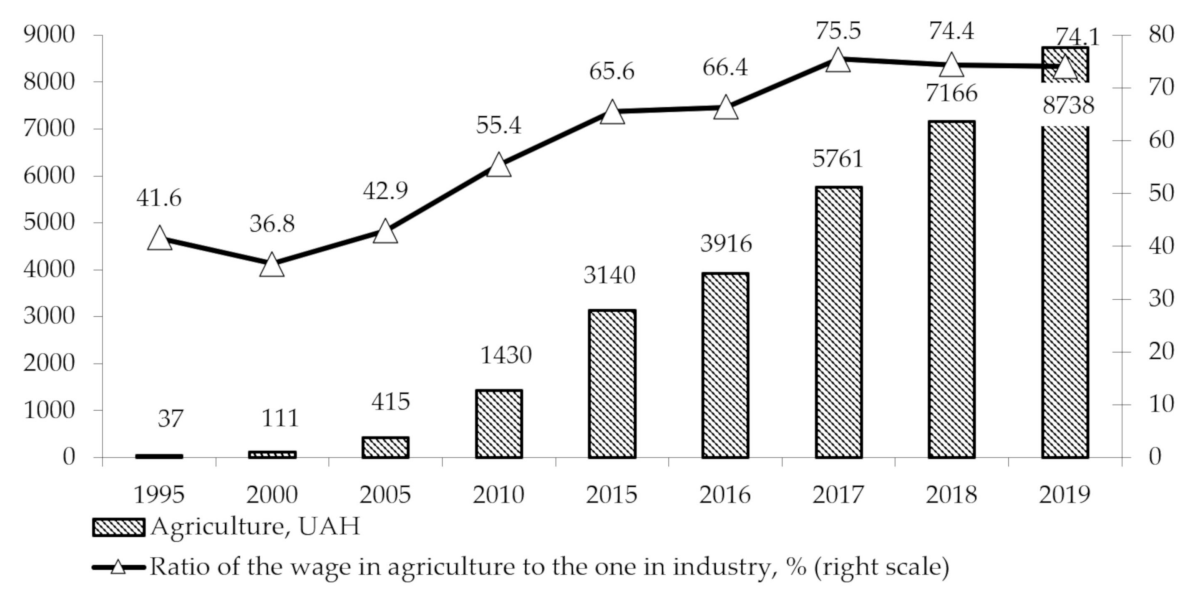

Figure 2. Dynamics of the average monthly wage in agriculture, calculated per one regular employee, UAH. Reference source: composed by the authors referring to the data of the State Statistics Service of Ukraine [62].

\subsection{Influence Factors on Employment in Ukraine's Agriculture}

Employment is a dynamic concept that is changed in time and space under the pressure of different conditions. Therefore, the effective solution of the problem of employment in agriculture is impossible without a complete analysis of the problem-causing factors. Given the diversity of influences and differences in the nature of their occurrence, it is advisable to systematize them. We propose to distinguish the current factors, influencing employment in the branch into groups, which are consolidated at the Figure 3.

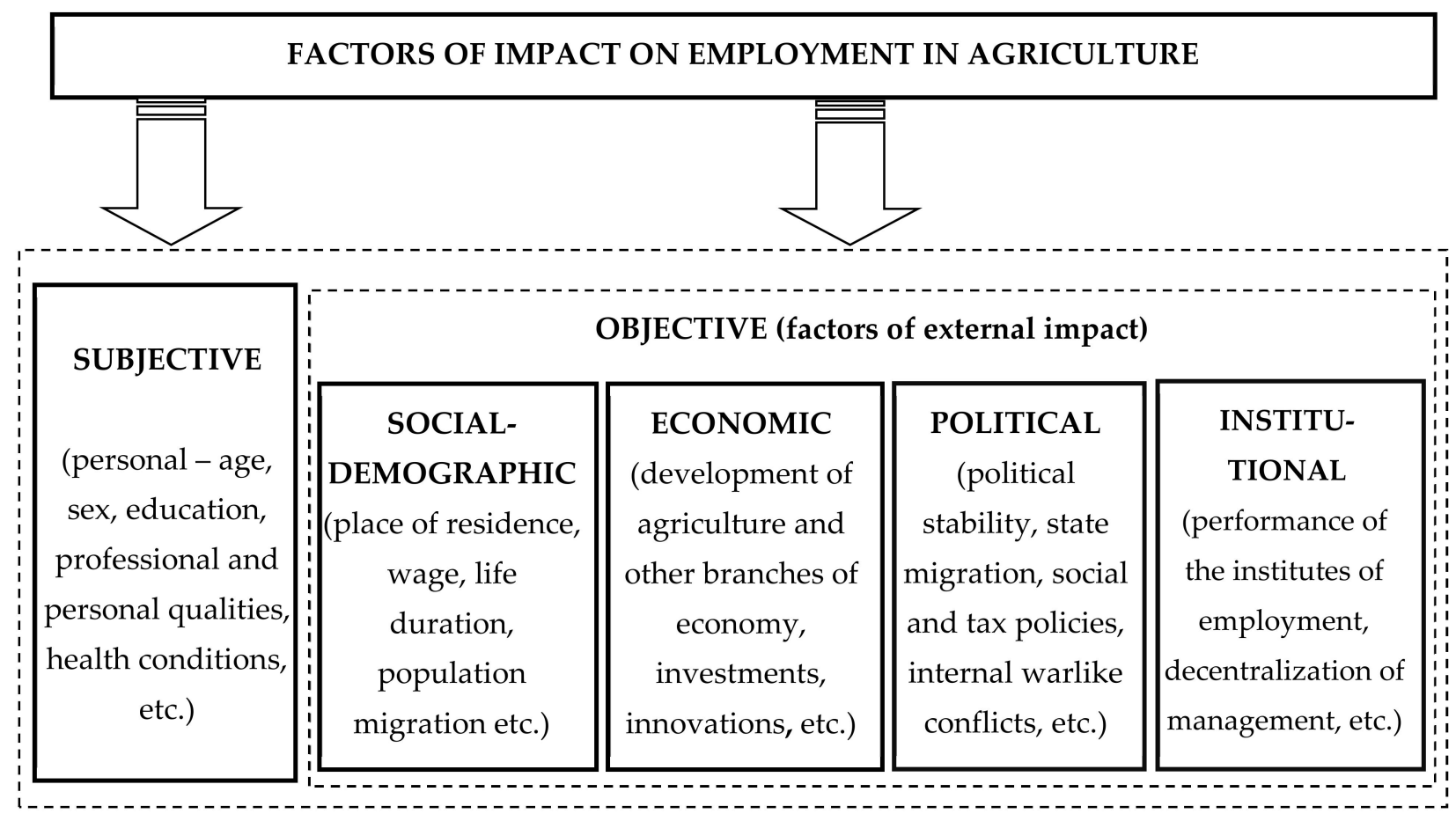

Figure 3. Factors of impact on employment in Ukraine's agriculture. Reference source: composed by the authors.

Subjective (individual) factors include age, gender, education, professional and personal qualities, self-employment ability, health status, and so on. According to research by Nartiuk, O. [4], the increase in the proportion of people who face age restrictions in employment correlates with increasing age. On the other hand, gender in most cases does not play a significant role in the employment of the economically active population in agriculture. However, there may be cases where the lack of a sufficiently developed 
infrastructure of pre-school institutions in rural areas can be an obstacle to employment for women who have children of preschool and primary school age. Lack of modern vocational education also has a negative impact on employment. The presence of chronic diseases or deterioration of health is also a good reason for refusing employment. Thus, according to a study by Nartiuk, O., $36 \%$ of employers believe that the presence of illness in employees leads to improper performance of their duties and requires frequent replacement of the absent employee and redistribution of his responsibilities [4].

According to the results of the study, it is established that employment in Ukraine's agriculture depends mainly on objective factors, namely on the population, including being able-bodied, wages, agricultural development, production volumes and structure, availability of a sufficient number of market-forming enterprises, migration processes, employment institutions, state social policy measures, political stability, etc., which are at the same time factors of external influence. Thus, the reduction in the working population reduces the supply of labor in the rural labor market. Lower wages in agriculture compared to other industries demotivate workers and promote their migration to cities. Reducing the number of enterprises, reducing the scale of their activities limit the labor demand. Employment is a dynamic concept that is changed in time and space under the pressure of different conditions.

In their integrity, those factors and various combinations of their components create social stereotypes relating to the quality of labor force and the models of behavior of the labor market entities, respectively, which directly or indirectly influence employment in the branch.

To assess the factors' impact on employment in Ukraine's agriculture, the authors applied modeling.

\subsection{Modeling of Employment in Ukraine's Agriculture and Assessment of the Degree of Main Factors Impact}

According to the results of the research on the number of people, engaged in agriculture (a dependent variable, depicted by the Figure 4), and referring to the data of the State Statistics Service of Ukraine [62], various stages have been specified.

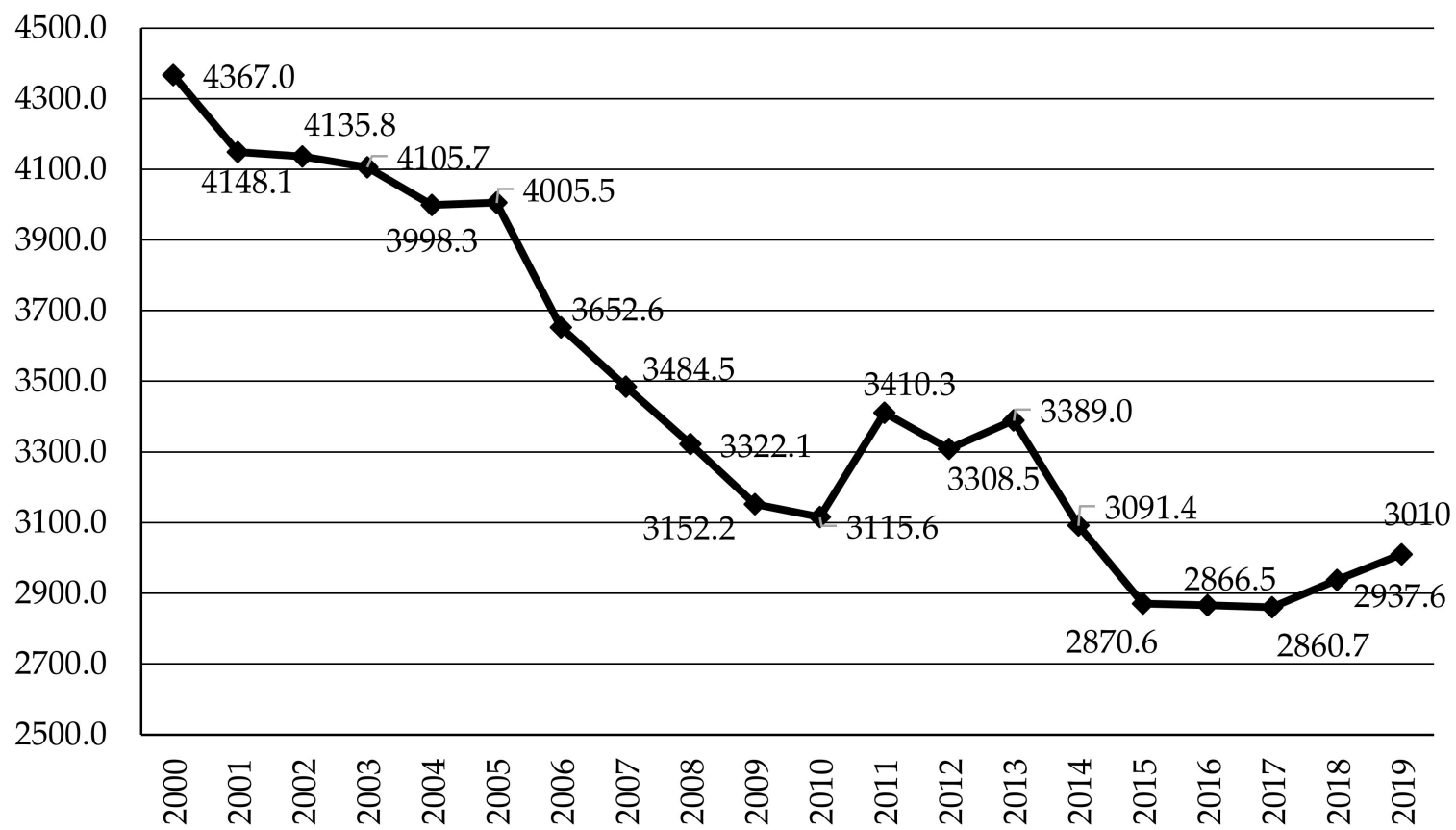

Figure 4. Number of population, employed in Ukraine's agriculture in the period of 2000-2019, thousand people. Reference source: composed by the authors referring to the data of the State Statistics Service of Ukraine [62]. 
Thus, during the period of 2000-2010 and 2014-2017, the branch experienced negative tendencies. In particular, the number of people employed in agriculture in those periods was reduced at the annual average rates of 3.3 and 5.3\%, respectively. In 2011-2013, one observed some improvement of the situation at the rural labor market, particularly as the number of people employed in the studied branch increased at the annual average rate of $4.8 \%$. In 2018, a new trend of growth was initiated, and it continued in 2019.

Agriculture as a source of employment in the primary sector faces a long term trend of sectoral decline everywhere, the result of economic development, and the EU is no exception [49].

Modeling of employment in agriculture as a branch of the national economy and examination of the degree of impact of the main factors are made by applying the method of factor analysis to develop a regression equation on the whole time interval (20002019) of collected relevant data, which are depicted in the Appendix A, Table A1. The main task of factor analysis is to reduce the number of variables (data reduction) and to determine the structure of relationships between variables. To conduct the study, the authors analyzed 23 indicators. The authors used statistical data, which were the socialdemographic and economic factors of impact on the dynamics of the indicator of the number of people employed in agriculture. In particular, social-demographic factors include the rural population at the age 16-64 (working population), registered unemployed people among the rural population, labor demand in agriculture, wage in the branch, etc. In the study, the authors in assessing the impact of factors on employment in agriculture took into account the working population. According to the current legislation, namely the Law of Ukraine “On Employment” of 05.07.2012 № 5067-VI (as amended), the working population is persons over 16 years of age who have not reached the retirement age. Sixteen years is the age from which employment is allowed according to the current legislation of Ukraine and 64 years is the age before retirement.

Economic factors influencing the dynamics of the indicator of the employment in the branch first determine the GDP of agriculture, investments in agriculture, export and import of agricultural products and a set of other factors, which can influence the number of employed people, for example time trend, gross added value in agriculture, agricultural production, labor productivity, share of animal production and crop production in the total outcome, amounts of sold products and other indicators (Appendix A, Table A1). The structure of agricultural production is a significant factor that affects employment in Ukraine's agriculture. Crop production, unlike animal production, is less labor-intensive. In recent years in Ukraine there is a steady trend to increase the share of crop production in the structure of agricultural production. If in 1990 the share of crop production was $51.5 \%$ of the total, in 2018 - already 73.7\%. Accordingly, the share of animal production as a more labor-intensive industry has decreased, livestock is declining, livestock complexes are closing, leading to the dismissal of workers in the sector, and this has a negative impact on employment in agriculture in general. Unemployed workers in the short term will not be able to retrain to work in crop production. In addition, crop production does not require such a large number of workers dismissed from animal production.

Next, the method of correlation and regression analysis was used to identify relations between the factors, they were studied for collinearity. Therefore, the research results determine the functional dependence between the factors of product outcome and labor productivity, index of agricultural products and net export of agricultural products, between the gross production and the share on animal products in it. Moreover, the impact of some factors on the resultant value was doubtful. Therefore, the following research and building of the model were based on the figures of the reliable factors of impact (Table 4). 
Table 4. Initial data for the model building.

\begin{tabular}{|c|c|c|c|c|c|c|c|}
\hline \multirow[b]{2}{*}{ Year } & \multirow{2}{*}{$\begin{array}{c}\text { Resultant } \\
\text { Value } \\
\text { Employment in } \\
\text { Agriculture, } \\
\text { Thousand } \\
\text { People }\end{array}$} & \multicolumn{3}{|c|}{ Social-Demographic Factors } & \multicolumn{3}{|c|}{ Economic Factors } \\
\hline & & $\begin{array}{l}\text { Rural } \\
\text { Population at } \\
\text { the Age 16-64, } \\
\text { Thousand } \\
\text { People }\end{array}$ & $\begin{array}{c}\text { Labor Demand } \\
\text { in AgriCulture, } \\
\text { Thousand }\end{array}$ & $\begin{array}{l}\text { Ratio of the } \\
\text { Wage in the } \\
\text { Agriculture to } \\
\text { the Wage in the } \\
\text { Economy, \% }\end{array}$ & $\begin{array}{l}\text { Agricultural } \\
\text { Production per } 1 \\
\text { Employed in } \\
\text { Agriculture, } \\
\text { Thousand }\end{array}$ & $\begin{array}{l}\text { Ratio of } \\
\text { Investments } \\
\text { to the GDP } \\
\text { (Agriculture) }\end{array}$ & $\begin{array}{l}\text { Net Export of } \\
\text { Agricultural } \\
\text { Products, } \\
\text { Million USD }\end{array}$ \\
\hline & $\mathrm{Y}$ & $\mathrm{X}_{1}$ & $X_{2}$ & $X_{5}$ & $X_{7}$ & $\mathrm{X}_{11}$ & $X_{16}$ \\
\hline 2000 & 4367 & 10,104 & 8.2 & 58.3 & 35 & 0.020 & 327 \\
\hline 2001 & 4148 & 10,072 & 9.3 & 48.6 & 40 & 0.053 & 683 \\
\hline 2002 & 4136 & 10,028 & 7.1 & 47.3 & 41 & 0.063 & 1138 \\
\hline 2003 & 4106 & 9913 & 7.6 & 45.5 & 37 & 0.071 & 304 \\
\hline 2004 & 3998 & 9801 & 9.4 & 50.0 & 45 & 0.088 & 1031 \\
\hline 2005 & 4006 & 9690 & 10.4 & 51.5 & 45 & 0.121 & 1402 \\
\hline 2006 & 3653 & 9585 & 8.1 & 53.1 & 50 & 0.176 & 1027 \\
\hline 2007 & 3485 & 9507 & 7.3 & 54.3 & 49 & 0.198 & 842 \\
\hline 2008 & 3322 & 9464 & 4 & 59.6 & 61 & 0.258 & 3196 \\
\hline 2009 & 3152 & 9446 & 2.2 & 63.3 & 63 & 0.143 & 3103 \\
\hline 2010 & 3116 & 9433 & 2.7 & 63.2 & 63 & 0.130 & 1942 \\
\hline 2011 & 3410 & 9468 & 2.9 & 67.4 & 69 & 0.147 & 3617 \\
\hline 2012 & 3496 & 9462 & 2.5 & 66.6 & 64 & 0.164 & 6035 \\
\hline 2013 & 3578 & 9439 & 2.3 & 69.1 & 71 & 0.137 & 5398 \\
\hline 2014 & 3091 & 9391 & 1.6 & 71.1 & 81 & 0.114 & 6595 \\
\hline 2015 & 2871 & 8791 & 1.2 & 74.9 & 83 & 0.122 & 7100 \\
\hline 2016 & 2867 & 8736 & 1.5 & 75.6 & 89 & 0.178 & 6958 \\
\hline 2017 & 2861 & 8672 & 2.2 & 81.1 & 87 & 0.209 & 8226 \\
\hline 2018 & 2938 & 8608 & 2.5 & 80.8 & 92 & 0.180 & 8649 \\
\hline 2019 & 3010 & 8537 & 5.1 & 83.2 & 91 & 0.164 & 11,325 \\
\hline
\end{tabular}

Reference source: composed by the authors referring to the data of the State Statistics Service of Ukraine [62].

Results of the analysis of the impact of social-demographic and economic factors on employment in the branch are presented in the Tables 5 and 6.

Table 5. Results of the regression analysis of the impact of social-demographic factors on employment in Ukraine's agriculture.

\begin{tabular}{ccccccc}
\hline & BETA & $\begin{array}{c}\text { Standard } \\
\text { Error }\end{array}$ & B & $\begin{array}{c}\text { Standard } \\
\text { Error }\end{array}$ & t(16) & $p$-Level \\
\hline Intercept term & & & -6502.35 & 1935.555 & -3.35942 & 0.003987 \\
$\mathrm{X}_{1}$ & 0.898442 & 0.156311 & 906.32 & 157.683 & 5.74778 & 0.000030 \\
$\mathrm{X}_{2}$ & 0.545929 & 0.104203 & 86.72 & 16.552 & 5.23907 & 0.000081 \\
$\mathrm{X}_{5}$ & 0.395249 & 0.187279 & 16.32 & 7.732 & 2.11049 & 0.050910 \\
\multicolumn{2}{c}{$\mathrm{R}=0.96717527, \mathrm{R}^{2}=$} & 0.93542801, Adjusted $\mathrm{R}^{2}=0.92332076, \mathrm{~F}(3.16)=77.262$ \\
\hline
\end{tabular}

Reference source: calculated by the authors.

Table 6. Results of the regression analysis of the impact of economic factors on employment in Ukraine's agriculture.

\begin{tabular}{ccccccc}
\hline & BETA & $\begin{array}{c}\text { Standard } \\
\text { Error }\end{array}$ & B & $\begin{array}{c}\text { Standard } \\
\text { Error }\end{array}$ & t(16) & $p$-Level \\
\hline Intercept term & & & 5540.99 & 206.6223 & 26.81701 & 0.000000 \\
$\mathrm{X}_{7}$ & -1.36555 & 0.213007 & -34.86 & 5.4381 & -6.41085 & 0.000009 \\
$\mathrm{X}_{11}$ & -0.18459 & 0.080919 & -1581.36 & 693.2271 & -2.28115 & 0.036574 \\
$\mathrm{X}_{16}$ & 0.57851 & 0.197338 & 0.09 & 0.0295 & 2.93159 & 0.009778 \\
\multicolumn{2}{c}{$\mathrm{R}=0.96717527, \mathrm{R}^{2}=$} & 0.93542801, Corrected $\mathrm{R}^{2}=0.92332076, \mathrm{~F}(3.16)=77.262$ \\
\hline
\end{tabular}

Reference source: calculated by the authors.

Therefore, the equations get the form: 
impact of social-demographic factors on employment:

$$
Y=-6502.35+0.898 \times X_{1}+0.546 \times X_{2}+0.395 \times X_{5}
$$

impact of economic factors on employment:

$$
Y=5540.99-1.366 \times X_{7}-0.185 \times X_{11}+0.579 \times X_{16}
$$

The regression equations have satisfactory econometric properties, in particular they are checked for the absence of multicollinearity. Moreover, the hypothesis on distribution of the residuals by the normal law, absence of autocorrelation and residuals heteroscedasticity is tested.

The equation consistency is confirmed by the obtained correlation factor and regression coefficients. The dependences are accurate by the Fisher test, as well as coefficients of the equation under the variables, which confirms the substantiality of the selected factors' impact on the resultant value, i.e., on the number of people employed in the branch, with the probability of 0.95 , are statistically significant.

According to the results of the conducted multiple regression analysis, it is reasonable to make the following conclusions: all social-demographic factors have direct impact on the resultant value (Equation (1)). In particular, an increase in the rural population aged 15-64 by one thousand people, the growth of the demand for labor force by one thousand people, and a $1 \%$ raise in the share of the branch wage in the economy cause the employment increase in the branch by $0.898 ; 0.546$ and 0.395 thousand people, respectively, relating to the average values in the sample.

The two first economic factors, particularly agricultural production per one employed in agriculture and ratio of investments to the GDP, make a reverse influence on the resultant value, whereas an increase in the net export results in a growth of the number of people employed in the branch. Referring to the Equation (2) coefficients, one can conclude that a raise in labor productivity by UAH 1 thousand per one employed person, increase in the ratio of investments to the GDP by $1 \%$, and reduction in the net export by USD 1 million cause a decrease in the number of people employed in agriculture by 1.366, 0.185 and 0.579 thousand people, respectively, relating to the average values in the sample.

To assess the impact of each separate factor on employment in the branch, the authors made calculations of the partial correlation factors, which demonstrated that the most significant social-demographic factors of impact included the first (rural population at the age 16-64) and the second factors (demand for labor force in agriculture) $\left(r_{y x_{1} \cdot x_{2} x_{5}}=0.82\right.$ and $r_{y x_{2} \cdot x_{1} x_{5}}=0.79$ ). The most important economic factor is labor productivity (agricultural production in constant prices of 2010 per 1 employed in agriculture $\left(r_{y x_{7} \cdot x_{11} x_{16}}=-0.84\right)$.

The model obtained based on correlation-regression analysis includes quite a lot of parameters, some of which are characterized by significant correlation (multilinearity). Therefore, there is a need to create a simplified model that should describe the source data as accurately as possible. To reduce the model size, the principal component analysis [63] was used. The principal components method is designed to evaluate large models and to estimate the parameters of the model, if it includes multicollinear variables [64]. Using the principal components method, we can express several factors through one, namely, combine them and work with a simpler model. It is impossible to avoid the loss of information, but the principal components method minimizes these losses [65]. Therefore, $X_{1}, X_{2}, X_{5}$ can be substituted by one variable, i.e., the main component $U_{1}$, whereas $X_{7}, X_{11}, X_{16}$-by the main component $\mathrm{U}_{2}$.

The Eigen values of the initial data are calculated and used to develop a diagram (Figure 5). 


\begin{tabular}{|c|c|c|c|c|}
\hline $\begin{array}{c}\text { Value } \\
\text { Number }\end{array}$ & $\begin{array}{c}\text { Eigen } \\
\text { Value }\end{array}$ & $\begin{array}{c}\text { \% total } \\
\text { Variance }\end{array}$ & $\begin{array}{c}\text { Cumulative } \\
\text { Eigen value }\end{array}$ & $\begin{array}{c}\text { \%ulative } \\
\text { \% }\end{array}$ \\
\hline 1 & 2.587333 & 86.24442 & 2.587333 & 86.244 \\
\hline 2 & 0.342791 & 11.42636 & 2.930123 & 97.671 \\
\hline 5 & 0.069877 & 2.32922 & 3.000000 & 100.000 \\
\hline
\end{tabular}

\begin{tabular}{|c|c|c|c|c|}
\hline $\begin{array}{c}\text { Value } \\
\text { Number }\end{array}$ & $\begin{array}{c}\text { Eigen } \\
\text { Value }\end{array}$ & $\begin{array}{c}\text { \% Total } \\
\text { Variance }\end{array}$ & $\begin{array}{c}\text { Cumulative } \\
\text { Eigen Value }\end{array}$ & $\begin{array}{c}\text { Cumulative } \\
\%\end{array}$ \\
\hline 7 & 2.346657 & 78.22189 & 2.346657 & 78.2219 \\
\hline 11 & 0.603821 & 20.12736 & 2.950478 & 98.3493 \\
\hline 16 & 0.049522 & 1.65075 & 3.000000 & 100.0000 \\
\hline
\end{tabular}

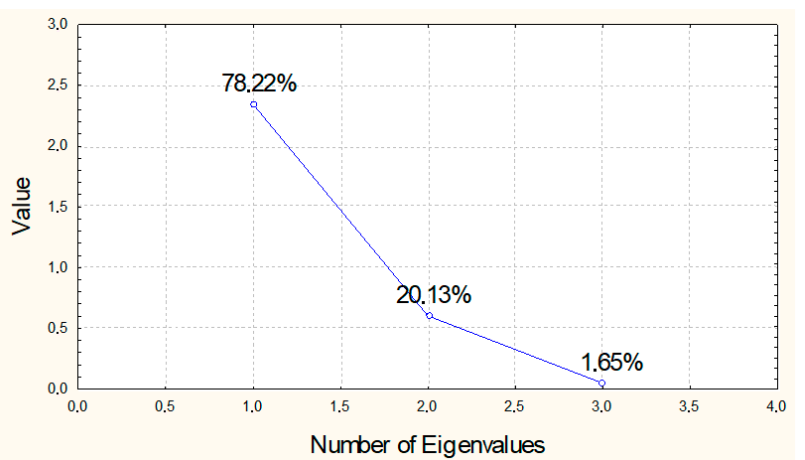

Economic factors

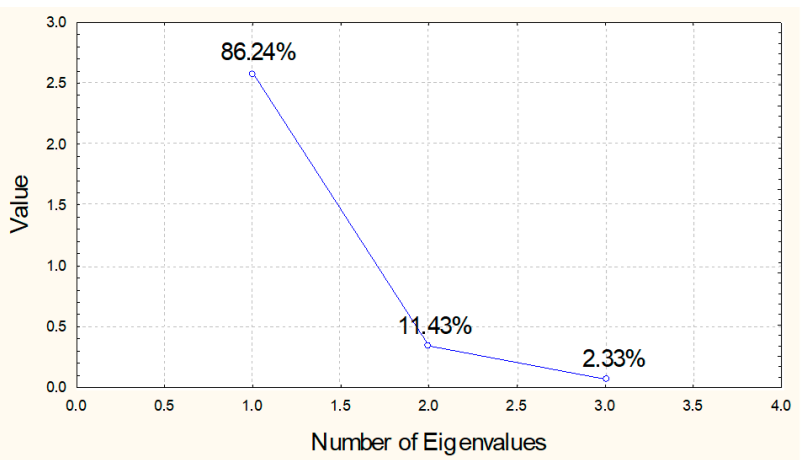

Social-demographic factors

Figure 5. Diagrams of the Eigen values of correlation matrices. Reference source: calculated and developed by the authors.

According to the Kaiser criterion, the number of factors is equal to the number of components with the proper values above 1 . Thus, $86.24 \%$ of the scatter of the initial parameter $\mathrm{Y}$ are caused by a change of the main component (marked as $\mathrm{U}_{1}$ ) of the socialdemographic factors and $78.22 \%$ - of the economic factors $\left(\mathrm{U}_{2}\right)$.

The above-presented results of application of the principal component analysis (Table 7) confirm that

$$
\begin{aligned}
& \mathrm{U}_{1}=-0.5797 \times \mathrm{X}_{1}-0.5466 \times \mathrm{X}_{2}+0.6043 \times \mathrm{X}_{5} \\
& \mathrm{U}_{2}=-0.631 \times \mathrm{X}_{7}-0.481 \times \mathrm{X}_{11}-0.6087 \times \mathrm{X}_{16}
\end{aligned}
$$

Table 7. Eigen vectors of the correlation matrices.

\begin{tabular}{cccc}
\hline Variable & Factor $\mathbf{1}$ & Factor $\mathbf{2}$ & Factor 3 \\
\hline$X_{1}$ & -0.579672 & 0.555480 & -0.596174 \\
$X_{2}$ & -0.546578 & -0.807690 & -0.221109 \\
$X_{5}$ & 0.604345 & -0.197685 & -0.771808 \\
$X_{7}$ & -0.630992 & 0.254396 & 0.732893 \\
$X_{11}$ & -0.480965 & -0.869522 & -0.112270 \\
$X_{16}$ & -0.608705 & 0.423337 & -0.671017 \\
\hline
\end{tabular}

Reference source: calculated and developed by the authors.

Therefore, the dependence of employment in Ukraine's agriculture on the two groups of factors can be described by a two-variable linear equation:

$$
\mathrm{Y}=-6486.93-1.8198 \mathrm{U}_{1}-0.0445 \mathrm{U}_{2}
$$

Application of the principal component analysis has supplied systematization and complex assessment of the impact of social-demographic and economic factors on employment in the branch.

\section{Discussion}

Considering the important place of agriculture in Ukraine's economy, the negative employment situation is a potential threat not only for its effective development, but 
also for the sustainable social development and economic safety of the state in general. For example, in the agricultural sector of the EU, the employment rate is continuously decreasing due to farms becoming bigger and more productive [49]. A similar scenario awaits Ukraine.

This paper has discussed the determination of the factors of impact on employment in Ukraine's agriculture and assessed the degree of their influence.

Summarizing the studies $[2-4,6,8,9,11-16,18,20,22,25,27-32,35]$ on determining the factors that impact employment in agriculture, including in the context of globalization processes, and taking into account the results of their own observations, the authors propose to classify the modern factors, influencing employment in the branch, into two groups: subjective (personal) and objective (of external impact). The last ones are divided into social-demographic, economic, political and institutional.

Given that each country, and, accordingly, the agriculture in it, has its own peculiarities and differences related to geographical location, natural and climatic factors, dynamics of economic development, availability of resources, etc., we consider it incorrect to impose the results of our research on other economics. However, it should be noted that some conclusions coincide. In particular, Kerstin, N. and Ostermeier, M. [18], Sumedh, R. [24] confirm in their research the negative impact of increasing investments and agricultural production on employment in agriculture. Sumedh, R. [24] developed his thought, arguing that the relationship between production and employment can varies as a result of the type of produce, the structure of the business. Our conclusion that the forced need for agricultural enterprises to raise wages of employees will lead to their layoffs and, consequently, to a decrease in employment in agriculture, confirmed by Petrick, M. and Zier, P. in their research [29].

The paper has used a factor analysis, multiple regression analysis and principal components method for modelling and evaluating the impact of various factors on the employment in agriculture of Ukraine, has introduced and discussed the relevant parameters derived from the large sets proposed in the literature, and has provided evidence of the solution's effectiveness through a discussion of the modelling result. This approach gave a perfect image of the state of the matter. The principal component method was used for presentation of the model of employment in agriculture in a more compact and elegant form without losing the least bit of information. However, further studies are still necessary to improve the methodology and the possibility of including more indicators into the model.

\section{Conclusions}

To sum up the conducted research on the determination of the factors of impact on employment in Ukraine's agriculture and to assess the degree of their influence, it is necessary to make the following conclusions.

The number of people engaged in Ukraine's agriculture decreased by $31 \%$ for the period 2000-2019. The authors identified such factors that caused this negative trend: changes in the structure of agricultural production (the volume of agricultural production in crop production, being a less labor consuming branch, has recently increased, whereas animal production has decreased), reduction in the sphere of agricultural work application, disproportion of the conjuncture of rural labor markets, deficit of job vacancies, low labor productivity, low level of earnings, decrease in the economically active rural population, deformation of its age structure, etc.

To assess the degree of impact of each group on employment in agriculture, the factor analysis was used. The results of the conducted multiple regression analysis confirm that all social-demographic factors make a direct impact on employment in agriculture. In particular, an increase in rural population at the age 15-64 by one thousand people, raise in the demand for labor force by one thousand people, and increase in the share of the wage earned in the branch by $1 \%$ in the economy cause a growth of employment in the branch by $0.898,0.546$ and 0.395 thousand people, respectively, relating to the 
average values in the sample. Based on the research results, it becomes clear that the state's social policy should primarily include measures to improve the demographic situation in rural areas, enhancing the living standards of the rural population, developing their professional skills and increasing productivity, reducing the differentiation between the incomes of rural and urban populations, to promote the development of an effective business environment. Because these socio-demographic factors have a positive impact on the employment in agriculture, the activation of business activity in agriculture, including through the diversification of activities, in particular the development of agricultural products processing, will contribute to the creation of new job places, extension of the spheres of labor application, etc. A growth in the share of wage in the branch referring to the wage in the economy in general indicates no discrimination of the income of the rural working-age population, raise in the value of rural work, and consequently will cease the outflow of the economically active population from the rural area, improve its age structure and contribute to an increase in the number of employed in agriculture.

Such economic factors as agricultural production per one employed in agriculture and ratio of investments to the GDP make a reverse influence on the resultant value, whereas an increase in the net export results in a growth of the number of employed in the branch. However, a raise in labor productivity by UAH 1 thousand per one employed person, and the ratio of investments to the GDP by $1 \%$, as well as reduction in the net export by USD 1 million force reduction in the number of people, employed in agriculture by $1.366,0.185$ and 0.579 thousand people, respectively, relating to the average values in the sample. The increase in production in Ukraine's agriculture is mainly associated with an increase in production efficiency, attraction of investments for its technical and technological improvement, modernization, automation of production processes and operations. Such scientific and technological progress inevitably leads to job place losses and, consequently, to a reduction in employment in the branch. Exports and imports instead create new job places, primarily related to servicing exports and imports directly. There is a need for specialists in the field of foreign trade, who are familiar with market research, international law, concluding foreign trade contracts, engaged in logistics, sales, etc. This explains the positive impact of net exports' growth on employment in agriculture.

The partial correlation factors demonstrate that the most significant social-demographic factors of impact include the rural population at the age 16-64 and the demand for labor force in agriculture. The most important economic factor is labor productivity (agricultural production in constant prices of 2010 per one employed in agriculture). The application of the principal component analysis has provided systematization and complex assessment of the impact of social-demographic and economic factors on employment in the branch.

In the light of the presented research, the authors definitely intend to continue working on the problem of employment in agriculture, arising from the action of numerous factors, both internal and external, which will also allow them to be present in the scientific discussion on an international forum. The promising directions of the further scientific search in the mentioned context suggest development of the state policy measures, argumentation of the methods and mechanisms of their implementation to regulate the situation, which is currently experienced at the rural labor market, and to solve the problems of employment in the domestic agriculture.

The authors plan to conduct a comparative analysis of the situation on the agricultural labor market of Ukraine and other countries, including the EU, to define common features and regional peculiarities, to identify opportunities for using European experience in providing employment in agriculture in Ukraine. Research methods will also be developed for forecasting the level of employment in agriculture under the impact of a single factor or a combination some of them.

Author Contributions: Conceptualization, N.P.; methodology, N.P. and O.G.; formal analysis, N.P., O.G. and A.K.; investigation, N.P. and O.G.; data curation, N.P. and O.G.; writing-original draft preparation, N.P. and O.G.; writing-review and editing, N.P., O.G., A.K., M.H. and B.R.; visualization, N.P. and O.G.; supervision, N.P., A.K., M.H. and B.R.; project administration, A.K. and M.H.; 
funding acquisition, M.H. and B.R. All authors have read and agreed to the published version of the manuscript.

Funding: The research is financed/co-financed under the Leading Research Groups support project from the subsidy increased for the period 2020-2025 in the amount of $2 \%$ of the subsidy referred to Art. 387 (3) of the Law of 20 July 2018 on Higher Education and Science, obtained in 2019.

Institutional Review Board Statement: Not applicable.

Informed Consent Statement: Not applicable.

Data Availability Statement: Not applicable.

Conflicts of Interest: The authors declare no conflict of interest.

\section{Appendix A}

Table A1. Symbol, title of the indicator and its impact on the employment in Ukraine's agriculture.

\begin{tabular}{|c|c|c|}
\hline $\begin{array}{l}\text { Indicator } \\
\text { Symbol }\end{array}$ & Indicator Description & $\begin{array}{l}\text { Expected Impact of the Indicator on the Number of } \\
\text { Employed People }\end{array}$ \\
\hline $\mathbf{Y}$ & Employment in agriculture, thousand people & dependent variable \\
\hline \multicolumn{3}{|c|}{ Social-demographic factors: } \\
\hline$X_{1}$ & $\begin{array}{l}\text { Rural population at the age } 16-64 \\
\text { thousand people }\end{array}$ & $\begin{array}{l}\text { An increase in the number of working-age rural population will } \\
\text { make a positive impact on employment in agriculture. }\end{array}$ \\
\hline$X_{2}$ & $\begin{array}{l}\text { Demand for labor in agriculture, } \\
\text { thousand people }\end{array}$ & $\begin{array}{l}\text { An increase in the demand for labor (creation of new job places, } \\
\text { extension of the spheres of labor application, etc.) will contribute } \\
\text { to a growth of employment in agriculture }\end{array}$ \\
\hline $\mathrm{X}_{3}$ & $\begin{array}{l}\text { Average monthly nominal wage in } \\
\text { agriculture, UAH }\end{array}$ & $\begin{array}{l}\text { The necessity to increase the salary of regular employees along } \\
\text { with the technological progress will result in firing of employees } \\
\text { and consequently reduction in employment in agriculture }\end{array}$ \\
\hline$X_{4}$ & $\begin{array}{l}\text { Average monthly nominal wage generally } \\
\text { in the economy, UAH }\end{array}$ & $\begin{array}{l}\text { An increase in the indicator and its excess above the level of wage } \\
\text { in agriculture will negatively influence the number of people, } \\
\text { employed in the branch, as it causes a transfer of the labor force } \\
\text { to more profitable branches of economy }\end{array}$ \\
\hline$X_{5}$ & $\begin{array}{l}\text { Ratio of the wage in the branch to the } \\
\text { wage in the economy, \% }\end{array}$ & $\begin{array}{l}\text { A growth of the share of wage in the branch referring to the wage } \\
\text { in the economy in general will contribute to an increase in the } \\
\text { number of employed in agriculture as it will confirm no } \\
\text { discrimination of the income of rural working-age population, } \\
\text { raise of the value of rural work, and consequently will cease the } \\
\text { outflow of economically active population from the rural area }\end{array}$ \\
\hline$X_{6}$ & $\begin{array}{l}\text { Registered unemployed people among } \\
\text { the rural population, thousand people }\end{array}$ & $\begin{array}{l}\text { Reduction in the indicator can make both positive impact of the } \\
\text { number of employed in agriculture due to an increase in the labor } \\
\text { demand, and negative one in case the change is related with the } \\
\text { loss of rural working-age population moving to cities or abroad }\end{array}$ \\
\hline \multicolumn{3}{|c|}{ Economic factors: } \\
\hline$X_{7}$ & $\begin{array}{l}\text { Agricultural production per one employed } \\
\text { in agriculture, thousand UAH }\end{array}$ & $\begin{array}{l}\text { An increase in the index will negatively influence the level of } \\
\text { employment in the branch by increasing efficiency of production, } \\
\text { its technical and technological improvement, introduction of new } \\
\text { highly productive crops and animal breeds }\end{array}$ \\
\hline$X_{8}$ & Real GDP, million UAH & $\begin{array}{l}\text { It will make indirect positive impact on the level of employment } \\
\text { in agriculture }\end{array}$ \\
\hline$X_{9}$ & $\begin{array}{l}\text { Gross added value of agriculture, } \\
\text { million UAH }\end{array}$ & $\begin{array}{l}\text { An increase in the level of gross added value confirms positive } \\
\text { structural changes in the branch, particularly an increase in the } \\
\text { share of products with a high added value, which indirectly } \\
\text { proves improvement in the employment situation }\end{array}$ \\
\hline
\end{tabular}


Table A1. Cont.

\begin{tabular}{|c|c|c|}
\hline $\begin{array}{l}\text { Indicator } \\
\text { Symbol }\end{array}$ & Indicator Description & $\begin{array}{l}\text { Expected Impact of the Indicator on the Number of } \\
\text { Employed People }\end{array}$ \\
\hline $\mathrm{X}_{10}$ & Investments in agriculture, million UAH & $\begin{array}{l}\text { A growth of investments can make contradictory effect, } \\
\text { particularly it can contribute to creation of new job places due to } \\
\text { improvement of logistic, construction of related production and } \\
\text { larger burden of the existing enterprises, as well as it may cause } \\
\text { reduction in employment because of the increased efficiency of } \\
\text { production in total (innovations, automation) }\end{array}$ \\
\hline$X_{11}$ & Ratio of investments to the GDP & $\begin{array}{c}\text { An increase in the ratio of investments to the GDP is an evidence } \\
\text { of the raised efficiency of production, technological progress, and } \\
\text { thus, will cause reduction in the employment level }\end{array}$ \\
\hline$X_{12}$ & $\begin{array}{l}\text { Volume of sold agricultural products } \\
\text { (goods, services), million UAH }\end{array}$ & $\begin{array}{l}\text { An increase in the volume of sold agricultural products } \\
\text { potentially means an increase in the number of employed in the } \\
\text { branch, because it is related with arrangement of new channels of } \\
\text { product sale, extension of transport shipping and distribution } \\
\text { network, etc. }\end{array}$ \\
\hline$X_{13}$ & $\begin{array}{c}\text { Share of animal products in agricultural } \\
\text { products, } \%\end{array}$ & $\begin{array}{l}\text { An increase in the outcome of animal products, being more labor } \\
\text { consuming branch, will contribute to a growth of the number of } \\
\text { people, employed in agriculture }\end{array}$ \\
\hline$X_{14}$ & Export of agricultural products, million USD & $\begin{array}{l}\text { Considering the fact that the share of crop products, being less } \\
\text { labor consuming branch, in the export amounts for above } 89 \% \text {, } \\
\text { an increase in exports will cause reduction in the number of } \\
\text { people, employed in the branch }\end{array}$ \\
\hline$X_{15}$ & Import of agricultural products, million USD & $\begin{array}{c}\text { An increase in imports can make contradictory impact on } \\
\text { employment. On the one hand, import displaces domestic } \\
\text { producers of the market reducing the number of people, } \\
\text { employed in that branch. On the other hand, import creates new } \\
\text { job places, particularly for the specialists, who are immediately } \\
\text { engaged in import transactions, logistic, sale at the domestic } \\
\text { market }\end{array}$ \\
\hline$X_{16}$ & Net export, million USD & $\begin{array}{l}\text { The indicator concerns the changes both in the volume of import } \\
\text { and export of agricultural products. A growth of the net export } \\
\text { (balance of foreign trade) due to increased export and reduced } \\
\text { import in total will contribute to the growth of the number of } \\
\text { employed in the branch }\end{array}$ \\
\hline
\end{tabular}

Reference source: composed by the authors.

\section{References}

1. Bandur, S.I. Modernization of the economy as a factor in the transformation of the employment structure. Rynok Praci ta Zajnjatist' Naselennja 2011, 2, 3-6.

2. Bulavka, O.G.; Dijesperov, V.S.; Kapinus, M.R.; Samofal, O.V.; Grabovs'ka, L.V. Zajnjatist' ta dohody naselennja u sil's'komu gospodarstvi. Rozvytok ekonomiky sil's'kogo gospodarstva Ukrai'ny v 2011-2015: Naukova dopovid' [Employment and Income of the Population in Agriculture. Ukraine's Agricultural Economy Development in 2011-2015: Scientific Report]; NNC «IAE»: Kyiv, Ukraine, 2016.

3. Gnybidenko, I.F.; Nartjuk, O.V. Faktory transformacii' zajnjatosti v sil's'kij miscevosti. Social'no-trudovi vidnosyny zajnjatosti: Suchasni tendencii', vyklyky, shljahy rozvytku: Monografija [Factors in the Transformation of Employment in Rural Areas. Socio-Labor Relations of Employment: Current Trends, Challenges, Ways of Development: Monograph]; Kolot, A., Gnybidenko, I., Eds.; KNEU: Kyiv, Ukraine, 2015.

4. Nartiuk, O.V. Subjective Aspects of Middle-Aged Employment in Redundant Regions of UKRAINE. Efektyvna Ekonomika, Volume 1. 2016. Available online: http:/ / www.economy.nayka.com.ua/ ?op=1\&z=4735 (accessed on 15 December 2020).

5. Grishnova, O.A. Trudovyj potencial ukrai'ny: Ocinka stanu, efektyonosti vykorystannja, strategichni naprjamy rozvytku: Monografija [Labor Potential of Ukraine: Assessment of the State, Efficiency of Use, Strategic Directions of Development: Monograph]; Grishnova, O.A., Ed.; MAKLAUT: Cherkasy, Ukraine, 2011.

6. Kurylo, I.O. Demographic processes and structures in Ukraine: Modern regional features. Aktual'ni Problemy Rozvytku Ekonomiky Regionu 2014, 10, 141-148. 
7. Cheren'ko, L.M.; Makarova, O.V. Ljuds'kyj rozvytokv Ukrai'ni: Transformacii' rivnja zhyttja ta regional'ni dysproporcii': Kolektyvna monografija [Human Development in Ukraine: Transformations of Living Standards and Regional Disparities: A Collective Monograph]; Libanova, E.M., Ed.; In-t demografii' ta social'nyh doslidzhen' im. V.M. Ptuhy NAN Ukrai'ny, Derzhkomstat Ukrai'ny: Kyiv, Ukraine, 2012.

8. Malik, M.; Mamchur, V. Self-employment and development of non-agricultural entrepreneurship in rural areas. Èkon. APK 2019, 4, 39-52. [CrossRef]

9. Gadzalo, J.M.; Zhuk, V.M.; Mogylova, M.M.; Bulavka, O.H.; Zakharchuk, O.V.; Kisil, M.I.; Korchynska, S.H.; Kropyvko, M.F.; Ksenofontov, M.M.; Luzan, Y.Y.; et al. Naukovi osnovy i strategichni priorytety stalogo rozvytku Sil's'kyh terytorij Ukrai'ny [Scientific Bases and Strategic Priorities of Sustainable Development of Rural Areas of Ukraine]; Gadzala, J.M., Ed.; NNC «IAE»: Kyiv, Ukraine, 2019.

10. Petrova, I.L. Substantive and structural aspects of innovative employment. Visnyk Prykarpats'Kogo Un Tu. Serija Ekonomika 2015, $11,172-176$.

11. Mogyl'nyj, O.M. (Ed.) Rynok praci sil's'koi' miscevosti: Stan ta perspektyvy funkcionuvannja: Zb. nauk. st. [Rural Labor Market: State and Prospects of Operation: Coll. Science. Art.]; In-t pidgotov. kadriv derzh. sluzhby zajnjatosti Ukrai'ny, DKS-centr: Kyiv, Ukraine, 2013.

12. Pavliuk, T.I. Peculiarities of population employment in agricultural households. Globalni ta Natsionalni Problemy Ekonomiky 2018, 23, 415-420.

13. Kukel, G.; Roleders, V.; Semchuk, I. Estimation of employment in agriculture of Ukraine. Problemy Systemnoho Pidkhodu v Ekonomitsi 2020, 1, 47-51. [CrossRef]

14. Rjabokon, V.P. Socio-economic problems of rural employment. Ekonomika APK 2012, 12, 95-99.

15. Mel'nyk, S.V.; Kosheleva, G.B.; Retivtsev, I.V. The problems of employment of rural population and ways of their solutions. Ukrainskyi Sotsium 2012, 2, 87-94. [CrossRef]

16. Cheong, D.; Jansen, M.; Peters, R. Shared Harvests: Agriculture, Trade and Employment; ILO and UNCTAD: Geneva, Switzerland, 2013. Available online: https://www.ilo.org/wcmsp5/groups/public/---ed_emp/documents/genericdocument/wcms_2128 68.pdf (accessed on 15 December 2020).

17. Ivanov, B.; Sokolova, E. The Role of Agriculture for Income and Employment in Bulgarian Rural Areas. In Proceeding of the International Scientific Conference, "Strategies for the Agri-Food Sector and Rural Areas—Dilemmas of Development", Licheń Stary, Poland, 19-21 June 2017; Multi-Annual Programme 2015-2019 “The Polish and the EU Agricultures 2020+. Challenges, Chances, Threats, Proposals", No 52.1. 2017. Available online: https://ssrn.com/abstract=3104614 (accessed on 15 December 2020).

18. Nolte, K.; Ostermeier, M. Labour Market Effects of Large-Scale Agricultural Investment: Conceptual Considerations and Estimated Employment Effects. World Dev. 2017, 98, 430-446. [CrossRef]

19. Lerman, Z. Hebrew University of Jerusalem Should agricultural employment in transition economies be encouraged? IZA World Labor 2017. [CrossRef]

20. Nahayo, A.; Omondi, M.O.; Zhang, X.; Li, L.; Pan, G.; Joseph, S. Factors influencing farmers' participation in crop intensification program in Rwanda. J. Integr. Agric. 2017, 16, 1406-1416. [CrossRef]

21. Rey, I.U.; Shakulikova, G.T.; Kozhakhmetova, G.A.; Lashkareva, O.V.; Bondarenko, E.G.; Bermukhambetova, B.B.; Baimagambetova, Z.A.; Zhetessova, M.T.; Beketova, K.N.; Anafiyaeva, Z. Labor Factor Efficiency in the Agricultural Industry. Int. J. Environ. Sci. Educ. 2016, 11, 9679-9691. Available online: https:/ / files.eric.ed.gov/fulltext/EJ1119059.pdf (accessed on 15 December 2020).

22. Roser, M. Employment in Agriculture. Our World in Data. 2014. Available online: https:// ourworldindata.org/employment-inagriculture (accessed on 15 December 2020).

23. Schwarcz, P.; Mura, L.; Pätoprstý, M.; Schwarczová, L. The impact of employment in agriculture on overall employment and development: A case study of the district of Topol'čany, Slovakia. SEER J. Labour Soc. Aff. East. Eur. 2012, 15, 483-492. Available online: https: / / www.jstor.org/stable/43293489?seq=1 (accessed on 15 December 2020). [CrossRef]

24. Sumedh, R. Employment Intensity of Growth in Agriculture. Tech. Rep. 2012. [CrossRef]

25. Tijani, B.A.; Benisheik, K.M.; Mustapha, A.B.; Dangaladima, W. Analysis of Factors Influencing Labour Supplied to Non-Farm Sub-Sector by Households in Mubi North Local Government Area of Adamawa State, Nigeria. Niger. J. Basic Appl. Sci. 2010, 18, 35-43. [CrossRef]

26. Kapur, R. Employment Opportunities in Rural Areas. Acta Sci. Agric. 2019, 3, 58-65. [CrossRef]

27. Koster, S.; Brouwer, A.E.; van Leeuwen, E.S. Diversity as the key to success? Urban and rural employment dynamics in the Netherlands. Reg. Stud. 2020, 54, 1187-1199. [CrossRef]

28. Petrick, M.; Zier, P. Regional employment impacts of Common Agricultural Policy measures in Eastern Germany. Agric. Econ. 2011, 42, 183-193. [CrossRef]

29. Petrick, M.; Zier, P. Common Agricultural Policy effects on dynamic labour use in agriculture. Food Policy 2012, 37, 671-678. [CrossRef]

30. Garibaldi, L.A.; Perez-Mendez, N. Positive outcomes between crop diversity and agricultural employment worldwide. Ecol. Econ. 2019, 164, 106358. [CrossRef]

31. Restuccia, D.; Yang, T.D.; Zhu, X. Agriculture and aggregate productivity: A quantitative cross-country analysis. J. Monet. Econ. 2008, 55, 234-250. [CrossRef] 
32. Chaplina, H.; Davidovaa, S.; Gorton, M. Agricultural adjustment and the diversification of farm households and corporate farms in Central Europe. J. Rural Stud. 2004, 20, 61-77. [CrossRef]

33. Urquía-Grande, E.; Rubio-Alcocer, A. Agricultural infrastructure donation performance: Empirical evidence in rural Ethiopia. Agric. Water Manag. 2015, 158, 245-254. [CrossRef]

34. Urquía-Grande, E.; Cano-Montero, E.I.; Pérez-Estébanez, R.; Chamizo-González, J. Agriculture, nutrition and economics through training: A virtuous cycle in rural Ethiopia. Land Use Policy 2018, 79, 707-716. [CrossRef]

35. Urquía-Grande, E.; del-Campo, C. Socio-economic factors determining the commitment to participate in an agricultural development project in rural Ethiopia. Iberoam. J. Dev. Stud. 2017, 6, 4-27. [CrossRef]

36. Bilan, Y.; Zos-Kior, M.; Nitsenko, V.; Sinelnikau, U.; Ilin, V. Social component in sustainable management of land resources. J. Secur. Sustain. 2017, 7, 107-120. [CrossRef]

37. Chemerys, V.; Dushka, V.; Maksym, V.; Solomonko, D. Business-model of rural areas development in Ukraine. Agric. Resour. Econ. 2019, 5, 154-176. Available online: http:/ / are-journal.com (accessed on 15 December 2020).

38. Kalyuzhna, J.; Pisarenko, D.; Nesterenko, S. Strategic management of labor resources of agricultural enterprises on the basis of marketing. Agric. Resour. Econ. 2018, 4, 55-68. Available online: http:/ / are-journal.com (accessed on 15 December 2020).

39. Kołodziejczak, W. Employment and Gross Value Added in Agriculture Versus Other Sectors of the European Union Economy. Sustainability 2020, 12, 5518. [CrossRef]

40. Kravchenko, O.; Kucher, A.; Hełdak, M.; Kucher, L.; Wysmułek, J. Socio-economic transformations in Ukraine towards the sustainable development of agriculture. Sustainability 2020, 12, 5441. [CrossRef]

41. Shvets, T.; Plotnikova, M.; Prysiazhniuk, O.; Kostyuk, L. Administrative and innovational approaches in social and business capital formation in the context of decentralization. Agric. Resour. Econ. 2019, 5, 152-170. Available online: http:/ / are-journal.com (accessed on 15 December 2020).

42. Stoyanets, N.; Zhao, H.; Li, G. Modernization of vocational education in the context of rural human resources development in China. Agric. Resour. Econ. 2020, 6, 76-90. Available online: http:/ /are-journal.com (accessed on 15 December 2020).

43. Tymoshenko, M. Identification of problems and prospects for development of social infrastructure of rural territories of Ukraine. Agric. Resour. Econ. 2018, 4, 129-143. Available online: http:/ / are-journal.com (accessed on 15 December 2020).

44. Vasyltsiv, T.; Lupak, R.; Kunytska-Iliash, M.; Levytska, O.; Mulska, O. Instruments of regional policy for human resources conservation by means of regulation of external youth migration of rural territories of the Carpathian region. Agric. Resour. Econ. 2020, 6, 149-170. Available online: http:/ / are-journal.com (accessed on 15 December 2020).

45. Yatsenko, O.; Nitsenko, V.; Karasova, N.; William, H.M.; Parcell, J.L. Realization of the Potential of Ukraine-EU Free Trade Area in Agriculture. J. Int. Stud. 2017, 10, 258-277. [CrossRef]

46. Hełdak, M.; Kucher, A.; Stacherzak, A.; Kucher, L. Structural transformations in agriculture in Poland and Ukraine: Towards economic sustainability. J. Environ. Manag. Tour. 2019, 1, 105-113. [CrossRef]

47. Stacherzak, A.; Hełdak, M. Borough Development Dependent on Agricultural, Tourism, and Economy Levels. Sustainability 2019, 11, 415. [CrossRef]

48. Furmankiewicz, M.; Janc, K.; Macken-Walsh, A. The impact of EU governance and rural development policy on the development of the third sector in rural Poland: A nation-wide analysis. J. Rural Stud. 2015. [CrossRef]

49. Modernising and Simplifying the CAP, Background Document Socio-Economic Challenges Facing EU Agriculture and Rural Areas. European Commission Directorate-General for Agriculture and Rural Development, Brussels, 11 December 2017; p. 37. Available online: https: / / ec.europa.eu/info/sites/info/files/food-farming-fisheries/key_policies/documents/soc_background_final_ en.pdf (accessed on 15 December 2020).

50. Smit, A. Dobrobut natsii. Doslidzhennia pro pryrodu ta prychyny dobrobutu natsii. [An Inquiry Into the Nature And Causes of the Wealth Of Nations]; Vasylieva, O.T., Lytvyna, Y., Eds.; Port-Royal: Kyiv, Ukraine, 2001.

51. Say, J.-B. Traktat po politicheskoy ekonomii. [A Treatise on Political Economy]; Bastia, F., Ed.; Delo, Akad. nar. hoz-va pri Pravitelstve Ros. Federatsii: Moskow, Russia, 2000.

52. Keynes, J.M. Obschaya teoriya zanyatosti, protsenta i deneg. [The General Theory of Employment, Money and Interest]. Available online: http:/ / ek-lit.narod.ru/ keynsod.htm (accessed on 15 December 2020).

53. Seligman, B. Osnovnyie Techeniya Sovremennoy Ekonomicheskoy Myisli. [Main Current in Modern Economics Economic Thought]; Progress: Moskow, Russia, 1968; Available online: http:/ / gallery.economicus.ru/ (accessed on 15 December 2020).

54. Lukas, R.E., Jr.; Sargent, T.J. Rational Expectations and Econometric Practice; University of Minnesota: Minneapolis, MN, USA, 1981.

55. Blaug, M. 100 Velikih Ekonomistov do Keynsa. [Great Economists before Keynes: A Introduction to the Lives and Works of 100 Economists of the Past]; Fofonova, A.A., Ed.; Ekonomicheskaya Shkola: Saint Petersburg, Russia, 2005.

56. Hansen, E. Ekonomicheskie Tsiklyi i Natsionalnyiy Dohod. [Business Cycles and National Income]. Available online: http://ek-lit.narod. $\mathrm{ru} /$ neoksod2.htm (accessed on 15 December 2020).

57. Hudokormov, A.G. Modern economic theory of the West (overview of the main trends). Voprosyi Ekonomiki 2008, 6, 22-51. Available online: http:/ /institutiones.com/theories/1044-sovremennaya-ekonomicheskaya-toriya-zapada.html (accessed on 15 December 2020).

58. Harrod, R.F. K teorii ekonomicheskoy dinamiki [Toward Economic Dynamics]; Gelios ARV: Moskow, Russia, 1999. 
59. UNDP. Bratislava Ot transformatsii-K obschestvu dlya vseh. Regionalnyiy doklad o chelovecheskom razvitii. [From Transformation-To Society for All. Regional Human Development Report]. Regionalnoe byuro PRO OON po stranam Evropyi i SNG. Bratislava. 2011. Available online: http://issuu.com/undp_in_europe_cis/docs/russianrhdrweb (accessed on 15 December 2020).

60. Schultz, T.W. Investment in Human Capital. Am. Econ. Rev. 1961, 51, 1-17.

61. Becker, G.S. Human Capital: A Theoretical and Empirical Analysis, with Special Reference to Education, 2nd ed.; Columbia University Press for NBER: New York, NY, USA, 1975.

62. The official site of State Statistics Service of Ukraine. Statistical Information (2000-2019). 2019. Available online: http:/ /www ukrstat.gov.ua/operativ/oper_new.html (accessed on 15 December 2020).

63. Electronic Textbook on Statistics StatSoft. Principal Components and Factor Analysis. Available online: http://www.statsoft.ru/ home/textbook/modules/stfacan.html (accessed on 15 December 2020).

64. Borychenko, O.V.; Cherniavskyi, A.V.; Ostapchuk, Y.Y. Application of the principal components method foe evaluation of energy efficiency level. Bull. Natl. Tech. Univ. Ser. New Solute. Mod. Technol. 2018, 16, 6-15. [CrossRef]

65. Kendyuhov, A.V.; Tolkachov, D.O. PCA method used in estimating of mashine-building enterprise competitiveness. Mark. Manag. Innov. 2013, 4, 219-227. Available online: https://mmi.fem.sumdu.edu.ua/sites/default/files/mmi2013_4_219_227.pdf (accessed on 15 December 2020). 